\title{
РЕАЛЬНІСТЬ ТА ПЕРСПЕКТИВИ ВПРОВАДЖЕННЯ НА СУЧАСНОМУ ЕТАПІ ДИСТАНЦІЙНОГО НАВЧАННЯ У СФЕРУ ОХОРОНИ ЗДОРОВ'Я
}

\author{
I. М. Мельничук, С. О. Ястремська
}

ДВНЗ “Тернопільський державний медичний університет імені І. Я. Горбачевського МОЗ Украӥни”

\section{DISTANCE LEARNING IN PUBLIC HEALTH: CURRENT STAGE AND PERSPECTIVES OF IMPLEMENTATION}

\author{
I. M. Melnychuk, S. O. Yastremska \\ I. Horbachevsky Ternopil State Medical University
}

\begin{abstract}
У статті розглянуто можливість і доцільність впровадження дистанційного навчання в медичну освіту. Представлені дані щодо тлумачення змісту, особливостей, переваг та недоліків використання дистанційної форми навчання в медичних навчальних закладах. Відображено сучасний погляд на впровадження дистанційного навчання в медицину та систему медичної освіти. Показано, що сучасні дистанційні технології навчання дають змогу проектувати і створювати інформаційні інструменти, які сприяють засвоєнню теоретичних знань медичної науки для опанування практичної частини зі спеціальності.
\end{abstract}

The article discusses the possibility and feasibility of implementation of distance learning in medical education. The interpretation of the content, features, advantages and disadvantages of distance learning in medical education is presented there. Current view on the introduction of distance learning into medicine and medical education system is also outlined. It is shown that modern distance learning technologies offer the opportunity to design and create information tools that facilitate the assimilation of theoretical knowledges of medical science to familiarize practical part of the specialty.

Вступ. Нагальним завданням розвитку сучасного суспільства є оновлення системи охорони здоров'я та медичної освіти. Реалізація цього завдання визначена Національною стратегією реформування системи охорони здоров’я в Україні на період 20152020 років і спрямована на модернізацію змісту медичної освіти, посилення діалогу та співпраці між студентами та викладачами, упровадження і реалізацію концепції навчання протягом життя, що веде до становлення принципово нової освітньої системи в медичних навчальних закладах. Така необхідність підсилюється й тим, що інтеграція України до Європейського освітнього простору, який базується на Болонському процесі, вимагає імплементації європейських стандартів у сфері надання освітніх послуг, де ключове місце посідає дистанційне навчання (ДН). Розвиток дистанційного навчання визнано одним з пріоритетних напрямів освітніх програм ЮНЕСКО: “Освіта для всіх”, “Освіта крізь все життя”, “Освіта без кордонів”.

Вихідні концептуальні положення щодо змісту й організації системи ДН в Україні грунтуються

(ㄱ) І. М. Мельничук, С. О. Ястремська на основних положеннях Концепції розвитку дистанційної освіти в Україні, Національної доктрини розвитку освіти, Державної програми "Інформаційні та комунікаційні технології в освіті і науці”, Національної стратегії розвитку освіти в Україні на 2012-2021 роки. Розвиток дистанційної освіти в системі охорони здоров'я зумовлений необхідністю впровадження новітніх методів та технологій медичної допомоги в практику лікувально-діагностичних закладів; оновленням та інтенсифікацією виробництва лікарських засобів, що вимагає удосконалення і підтримки безперервного навчання всіх категорій медичних працівників.

Аналіз останніх наукових розвідок і публікацій свідчить, що концептуальні ідеї дистанційного навчання у фаховій підготовці студентів досліджуються багатьма українськими (В. Биков [1], Г. Козлакова [3], В. Кухаренко [4], П. Стефаненко [6], Б. Шуневич [8] та ін.) і зарубіжними (О. Полат [5], S. Guri-Rosenblit [9], O. Peters [10] та ін.) науковцями. Дослідники висвітлюють теоретичні засади дистанційної освіти (Г. Козлакова [3]), проблему організації навчального процесу в системі дистан- 
ційного навчання і визначають перспективні шляхи її вирішення (П. Стефаненко [6], П. Федорчук [7] та ін.), конкретизують особливості становлення ДН в Україні (І. Блощинський [2]) та в зарубіжних країнах (Б. Шуневич [8]). Однак результати аналізу наукової літератури свідчать, що проблема дистанційного навчання в медицині та системі медичної освіти не знайшла всебічного вирішення в сучасних педагогічних дослідженнях.

Основна частина. Сьогодні не існує єдиного визначення поняття “дистанційне навчання”, що зумовлено термінологічною плутаниною та відсутністю єдиного розуміння змісту базових визначень, пов'язаних з цим терміном. Стосовно цього I. Блощинський зазначає, що протягом останніх 20 років 3'явилося близько тридцяти термінівеквівалентів, які є синонімічними (“викладання на відстані (“дистанційна освіта (distance/distant education)”, teaching at a distance)”, “електронне навчання (e-learning)”, “дистанційне навчання/викладання (distance learning/teaching)”), близькими за змістовною характеристикою (“відкрите навчання (open learning)”, “гнучке навчання (flexible learning)”, “безперервне навчання (continuous learning)”, “віртуальне навчання (virtual leartning)”). Науковці роблять додатковий наголос на різних рисах та цільових орієнтирах дистанційного навчання (“діалогове/онлайн навчання (online learning)”, “ресурсно-орієнтоване навчання (resource-based learning)”, “Інтернет-навчання/тренінг (Internetlearning/training)”) та ін. [2]. Спробуємо розібратися в цьому різноманітті, визначивши сутнісні особливості цього поняття.

У наукових колах існують різні погляди на дистанційне навчання - від його абсолютизації як нової універсальної форми навчання, спроможної змінити традиційну, до технології комплектування засобів і методів передачі навчальної інформації $[6,7,10]$. Так, визначаючи теоретичні і методичні засади дистанційного навчання у вищій школі, П. Стефаненко розглядає його як індивідуалізований процес професійної підготовки, який відбувається за опосередкованої взаємодії віддалених один від одного учасників навчального процесу у спеціалізованому середовищі, яке функціонує на базі сучасних психолого-педагогічних, інформаційно-комунікаційних технологій і систем мультимедіа та базується на принципі самостійного навчання студента [6]. Середовище навчання характеризується тим, що студенти частково, а іноді й зовсім віддалені від викладача в просторі і (чи) у часі, водночас вони мають можливість у будь-який момент підтримати діалог за допомогою засобів телекомунікацій.

Так, на думку В. Кухаренко, дистанційне навчання - це специфічна форма навчання, за якої їі суб’єкти віддалені в просторі. Вона реалізується з урахуванням передачі і стратегій інформації у віртуальному середовищі, забезпечується спеціальною системою організації навчального процесу, особливою методикою розробки навчальних посібників і стратегій викладання, а також з використанням електронних або інших комунікаційних технологій [4]. Тобто дистанційне навчання дає змогу задовольнити індивідуальні потреби кожного студента, вирішити такі проблеми традиційної освіти, як відсутність індивідуального підходу до студентів, слабка їхня мотивація до самостійної пізнавальної діяльності, недостатнє використання активних форм навчання, директивність освітнього процесу, суб’єктивність оцінки результатів навчання тощо.

Досліджуючи особливості дистанційного навчального процесу, В. Биков розглядає дистанційне навчання як цілеспрямовано організовану i погоджену в часі і просторі взаємодію викладачів та студентів між собою та із засобами навчання з використанням педагогічних, інформаційних і телекомунікаційних технологій [1]. Розробляючи адаптивну систему дистанційного навчання на базі інтелектуальних Інтернет-технологій, П. Федорчук тлумачить дистанційне навчання як гуманістичну особистісно зорієнтовану форму навчання, в основі якої закладено цілеспрямоване, вмотивоване учіння і спілкування студентів з викладачем та між собою засобами сучасних інформаційних технологій [7].

Отже, у дослідників немає одностайності тлумачень щодо змісту дистанційного навчання. Нині серед науковців поширені два підходи, які мають певні дидактичні відмінності. Так, згідно з першим підходом, обмін інформацією між викладачем та студентами відбувається за допомогою електронних мереж чи інших засобів телекомунікацій. 3 цих позицій студент є одержувачем певного інформаційного змісту і системи завдань для його засвоєння. Знання ж розглядаються як отримана трансльована інформація, проте діяльність студентів щодо конструювання знань майже не організовується.

Другий підхід є принципово іншим і передбачає інтеграцію інформаційних та педагогічних технологій, що забезпечують інтерактивність взаємодії суб’єктів освіти і продуктивність навчального процесу. Основними рисами цього типу дистанційного 
навчання є особистісний, креативний і телекомунікативний характер освіти. 3 позицій окресленого підходу в основі дистанційного навчання закладена особистісна продуктивна діяльність студентів, яка конструюється з використанням сучасних засобів телекомунікацій. Обмін і пересилання інформації відіграють, перш за все, роль допоміжного середовища організації продуктивної освітньої діяльності студентів. Зазвичай навчання відбувається в реальному часі (чат, відеозв'язок, спільні для віддалених викладачів і студентів “віртуальні дошки” із графікою тощо), а також асинхронно (телеконференції на основі електронної пошти, форуми). В процесі дистанційного навчання передбачається наявність викладача і студентів, їхнє спілкування, спілкування між собою, а також використання у системі необхідного комплексу засобів навчання [5]. Таким чином, у процесі дистанційного навчання кожним суб’єктом самостійно вибудовується індивідуальний віртуальний освітній простір, який відображає взаємозв'язок усіх сфер особистості: інтелектуальної, емоційної, ціннісно-смислової, поведінкової та ін. Процес розширення індивідуального віртуального освітнього простору відбувається внаслідок зовнішньої та внутрішньої психічної діяльності самого суб'єкта, його самопізнання, взаємопроникнення зовнішнього і внутрішнього.

Сьогодні дистанційне навчання розглядається як нова універсальна гуманістична форма освіти на базі інформаційно-телекомунікаційних технологій та шлях до демократизації, гуманізації та варіативності освіти, оскільки дозволяє студентам використовувати весь об' єм навчального матеріалу, сприяє організації самоосвіти з одночасною можливістю отримання консультацій викладача і контролю результатів роботи.

На основі наведеного узагальнюємо, що особливостями дистанційного навчання в системі медичної освіти у порівнянні з традиційним навчанням є:

1) технологічність - навчання з використанням сучасних програмних і технічних засобів сприяє ефективності електронної освіти. Нові технології дають змогу зробити візуальну інформацію медичного спрямування яскравою і динамічною, побудувати освітній процес з урахуванням активної взаємодії студента з навчальною системою;

2) розвиток Інтернет-мереж, швидкісного доступу до Інтернету, використання мультимедійних технологій, звуку, відео робить курси дистанційного навчання з клінічних дисциплін повноцінними і цікавими;
3) доступність і відкритість дистанційного навчання, що дає змогу студентам навчатися, перебуваючи фактично в будь-якій точці земної кулі;

4) модульність - в основі програм дистанційного навчання закладено модульний принцип. Кожна окрема дисципліна або низка дисциплін, що їх освоїли студенти, створюють цілісне уявлення про відповідну предметну сферу. Це дає змогу з переліку незалежних навчальних курсів сформувати навчальний план, який відповідає індивідуальним або груповим потребам студентів;

5) безпосередній контакт з відомими вітчизняними і зарубіжними фахівцями: відеоконференції, телефонні консультації, on-line навчання;

6) використання телемедицини - телеконференції, відеосемінари з актуальних питань медицини 3 провідними медичними установами, відеотрансляції з операційних для студентів, які навчаються дистанційно, консультації складних хворих з провідними медичними установами;

7) архівування отриманих знань;

8) індивідуалізація навчання за темпами освоєння матеріалу;

9) можливість вибудовування індивідуальних освітніх траєкторій;

10) реалізація продуктивного навчання, можливість самореалізації студентів і розкриття творчого потенціалу;

11) використання сучасних інформаційних систем: навчальні соціальні мережі, e-mail, електронні бібліотеки, комп’ютерні конференції, віртуальні і симулятивні конференції, майстер-класи, оцінка знань - on-line тестування;

12) яскраво виражена практичність навчання студенти можуть самостійно зробити вибір у послідовності вивчення дисциплін, в інтенсивності та тривалості занять. Переважає лабільність темпу навчання, відсутність жорсткої прив'язки до розкладу. Будь-які труднощі та проблеми вирішуються у будь-який момент за допомогою електронної пошти або зі своїм викладачем у режимі on-line, що сприяє високій мобільності навчання.

Таким чином, у процесі дистанційного навчання з використанням інформаційних технологій студенти медичних ВНЗ мають змогу опанувати всебічні технологічні знання, які є необхідними в майбутній практиці, оскільки для того, щоб повністю осягнути предметну сферу вивчення, студенти зазвичай використовують різні додаткові ресурси. Сучасні дистанційні технології навчання дають змогу проектувати і створювати інформаційні інструменти, 
які сприяють засвоєнню теоретичних знань медичної науки для опанування практичної частини зі спеціальності, яка вивчається. Наприклад, з використанням дистанційного навчання вивчення патології конкретного захворювання охоплює комплекс текстових документів з анатомії, фізіології, морфології (електронні лекції) з анатомо-фізіологічними особливостями. У лекціях, присвячених сучасним методам дослідження, подається інформація про лабораторні, інструментальні та інші види діагностики. Текстовий документ доповнюється ілюстративним матеріалом: таблицями, малюнками, схемами, алгоритмами діагностики і лікування, фотографіями мікро- і макропрепаратів, рентгеноі сонограмами, даними комп’ютерної томографії, ендоскопії тощо. Все це дає змогу майбутнім фахівцям медичної галузі в наочній формі краще засвоювати теоретичний матеріал.

Висновки. Підсумовуючи наведене, припускаємо, що система дистанційного навчання медичних

\section{Список літератури}

1. Биков В. Ю. Дистанційний навчальний процес : навч. посіб. / В. Ю. Биков. - К. : Міленіум, 2005. - 292 с.

2. Блощинський І. Г. Сутність та зміст поняття “дистанційне навчання” в зарубіжній та вітчизняній науковій літературі / I. Г. Блощинський // Вісник Національної академії Державної прикордонної служби України. 2015. - Вип. 3.

3. Козлакова Г. О. Інформаційно-програмне забезпечення дистанційної освіти: зарубіжний і вітчизняний досвід : [монографія] / Г. О. Козлакова. - К. : ВЦ “Просвіта", 2002. - 233 с.

4. Кухаренко В. М. Дистанційне навчання. Енциклопедичне видання : навч.-метод. посіб. / В. М. Кухаренко.-К. : ТОВ Редакція “Комп’ютер”, 2007. - 128 с.

5. Полат Е. С. Педагогические технологии дистанционного обучения : учеб. пособ. для студ. высш. учеб. заведений / Е. С. Полат, М. Ю. Бухаркина, М.В.Моисеева. -М. : Центр Академия, 2006. - 400 с. фахівців повинна мати такі складові: проведення дистанційних лекцій, семінарів $з$ поглибленим вивченням раніше прочитаного лекційного матеріалу; практичні заняття з різних методів діагностики та лікування, а також індивідуальні телемедичні консультації. Сучасні технології ДН дозволяють студентам не лише ознайомлюватися 3 лекціями провідних фахівців всього світу, але й активно взаємодіяти між собою та з викладачами. Використання технологій Інтернет, які є обов’ язковою умовою дистанційного навчання, уможливлює підвищення рівня теоретичних знань студентів, розвиток у них практичних навичок, наприклад, шляхом аналізу клінічних спостережень у складі навчальних груп. Усе це робить сучасну освіту набагато доступнішою для кожного медика, що, безсумнівно, в підсумку приведе до істотного підвищення якості надання медичної допомоги в Україні.

6. Стефаненко П. В. Теоретичні і методичні засади дистанційного навчання у вищій школі : дис. ... доктора пед. наук : 13.00.04 / Стефаненко Павло Вікторович. К., 2002. - 492 с.

7. Федорчук П. І. Адаптивна система дистанційного навчання та контролю знань на базі інтелектуальних Інтернет-технологій : автореф. дис. на здобуття наук. ступеня доктора техн. наук : 05.13.06. “Інформаційні технології” / П. І. Федорчук. - К., 2009. - 37 с.

8. Шуневич Б. І. Розвиток дистанційного навчання у вищій школі країн Європи та Північної Америки : автореф. дис. на здобуття наук. ступеня доктора пед. наук : 13.00.01 “Загальна педагогіка та історія педагогіки” / Шуневич Богдан Іванович. - К., 2008. - 509 с.

9. Guri-Rosenblit S. Distance education’ and “e-learning”: Not the same thing / Sarah Guri-Rosenblit // Higher Education. - 2005. - № 49 (4). - P. 467-493.

10. Peters O. Distance Education in Transition Developments and Issues (5th ed.) / Otto Peters. - Oldenburg : BIS-Verlag der Carl von Ossietzky Universität Oldenburg, 2010. - 284 p. 